\title{
Implementasi Sistem Penjaminan Mutu Internal (SPMI) di Sekolah Menengah Kejuruan (SMK)
}

\author{
Asnaul Lailina Nikmatuz Zahrok * \\ Universitas Negeri Malang. \\ Jl. Cakrawala No. 5, Sumbersari, Lowokwaru, Malang, Jawa Timur 65145, Indonesia. \\ * Corresponding Author. E-mail: asnaulnz@gmail.com
}

\section{ARTICLE INFO}

\section{Article History}

Received:

21 April 2020;

Revised:

8 September 2020;

Accepted:

10 September 2020

Available online:

25 September 2020

Keywords

Implementasi; Sistem Penjaminan Mutu Internal (SPMI); Sekolah Menengah Kejuruan (SMK); Implementation; Internal quality guarantee system; Vocational school

\begin{abstract}
Penulisan artikel ini bertujuan untuk mengetahui implementasi penjaminan mutu di SMK Negeri 35 Tulungagung. Jenis pendekatan yang digunakan ialah pendekatan kualitatif dengan metode deskripstif kualitatif. Hasil penelitian menunjukkan penjaminan mutu di SMKN 35 Tulungagung diawali dari Evaluasi Diri Sekolah (EDS) untuk memperoleh pemetaan capaian mutu dari setiap aspek Standard Nasional Pendidikan (SNP). Capaian mutu yang dirasa kurang selanjutnya diperbaiki melalui pemenuhan mutu secara berkelanjutan. Upaya pemenuhan mutu direncanakan oleh Tim Penjaminan Mutu Pendidikan Sekolah (TPMPS) yang dituangkan dalam bentuk dokumen perencanaan pemenuhan mutu. Di dalamnya diuraikan kegiatan, tujuan, strategi pelaksanaan, indikator keberhasilan, serta rincian biaya yang dibutuhkan. Selanjutnya rencana pemenuhan mutu direalisasikan kepada setiap aspek pembelajaran dengan melibatkan komponen pendidikan secara komprehensif. Pelaksanaan pemenuhan mutu dimonitoring oleh TPMPS secara berkelanjutan Seluruh pelaksanaannya kemudian dievaluasi untuk melihat efektifitas pelaksanaan dengan rencana pemenuhan mutu terhadap pencapaian SNP. Hasilnya akan dianalisis untuk penetapan standar standar mutu baru yang lebih efektif. Seluruh rangkaian tersebut didokumentasikan dalam bentuk rapor SPMI.
\end{abstract}

The purpose of this article is to determine the implementation of quality assurance in SMK 35 Tulungagung. This type of approach is a qualitative approach. The method used is descriptive qualitative. The results showed that quality assurance at SMK 35 Tulungagung started from School Self Evaluation (EDS) to obtain a mapping of quality achievements from every aspect of National Education Standards (SNP). Quality achievements that are felt to be lacking are subsequently corrected through continuous quality fulfillment. Efforts to fulfill quality are planned by the School Education Quality Assurance Team (TPMPS) as outlined in the form of quality fulfillment planning documents. It outlines the activities, objectives, implementation strategies, indicators of success, and details of the costs required. Furthermore, the quality fulfillment plan is realized for every aspect of learning by comprehensively involving the education component. TPMPS monitors the implementation of quality fulfillment on an ongoing basis. All implementation is then evaluated to see the effectiveness of implementing the quality fulfillment plan for the achievement of SNP. The results will be analyzed for setting new quality standards more effectively.

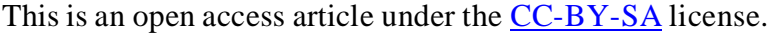

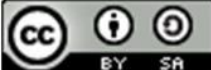

How to cite:

Zahrok, A. L. N. (2020). Implementasi sistem penjaminan mutu internal di Sekolah Menengah Kejuruan. Jurnal Akuntabilitas Manajemen Pendidikan, 8(2), 196-204. doi: https://doi.org/10.21831/jamp.v8i1.32867 


\section{PENDAHULUAN}

Pendidikan sampai saat ini masih menempati posisi pertama sebagai aspek yang dipandang paling berpengaruh dalam menentukan maju atau mundurnya suatu negara. Seiring dengan perkembangan zaman, tuntutan kebutuhan masyarakat akan pendidikan yang bermutu tinggi pun semakin tinggi. Indikator pendidikan yang bermutu ialah dihasilkannya Sumber Daya Manusia (SDM) yang dapat memenuhi persyaratan yang dituntut oleh pengguna jasa pendidikan (Qomar, 2010), dalam hal ini misalnya industri dan lapangan kerja tertentu. Dibandingkan dengan negara lain di kawasan Asia Tenggara seperti Malaysia dan Singapura, penguasaan kompetensi dan produktivitas sumber daya manusia di Indonesia dapat dikatakan sangat kurang. Hal ini ditandai dengan rendahnya daya saing dalam dunia kerja di luar negeri. Sekolah Menengah Kejuruan (SMK) seperti disebutkan dalam Peraturan Pemerintah Nomor 66 Tahun 2010 tentang Perubahan Atas Peraturan Pemerintah Nomor 17 Tahun 2010, merupakan bentuk satuan pendidikan formal yang menyelenggarakan pendidikan kejuruan pada jenjang pendidikan menengah sebagai lanjutan dari SMP, MTs, atau bentuk lain yang sederajat atau lanjutan dari hasil belajar yang diakui sama atau setara SMP atau MTs. Misi utamanya adalah untuk menyiapkan lulusan dari tingkat pendidikan menengah yang siap masuk dunia kerja.

SMK diyakini mampu menghasilkan lulusan dengan kreatifitas dan produktivitas yang tinggi, sehingga mampu menaikkan taraf perekonomian masyarakat (Putri, 2020). Hal ini karena pendidikan kejuruan bertujuan untuk menghasilkan manusia kerja, dalam artian manusia mandiri berdikari, tidak menjadi beban bagi keluarga, masyarakat, bangsa, dan negaranya. Mengacu pada tujuannya, pembelajaran di SMK berorientasi pada pengembangan kompetensi siswa untuk dapat menguasai dan melaksanakan pekerjaan tertentu. Kegiatan pembelajaran di SMK didominasi oleh kegiatan praktik yaitu sebanyak 70\%, dan sisanya adalah teori di dalam kelas. Hal ini sesuai dengan tujuannya untuk memberikan bekal keterampilan siswa dalam memasuki dunia kerja. Meskipun sebagian besar lulusannya dapat menembus berbagai industri, namun fakta jumlah pengangguran lulusan SMK lebih tinggi dibandingkan dengan lulusan lainnya tidak dapat dipandang sebelah mata. Berdasarkan data dari Badan Pusat Statisik (BPS) Republik Indonesia, Tingkat Pengangguran Terbuka (TPT) untuk Sekolah Menengah Kejuruan (SMK) pada Februari 2019 masih menjadi yang tertinggi diantara tingkat pendidikan lain, yaitu sebesar 8,63\% (Badan Pusat Statistik Republik Indonesia, 2019).

Sementara itu, hasil akreditasi jenjang pendidikan menengah atas tahun 2017, diketahui terdapat kurang lebih 1.060 SMK di Jawa Timur dengan status terakreditasi. 514 SMK mendapat peringkat A, 464 SMK mendapat B, dan 82 SMK mendapat peringkat C (pwmu.co, 2017) dengan kata lain lebih dari 50\% SMK di Jawa Timur belum memenuhi Standar Nasional Pendidikan (SNP). Hal tersebut merupakan salah satu indikator ketidakmampuan SMK untuk menjamin mutu pendidikannya sesuai dengan standar nasional pendidikan, yaitu meliputi penilaian hasil belajar, penyusunan perencanaan peningkatan mutu pendidikan, implementasi peningkatan mutu pendidikan, serta evaluasi proses pembelajaran (Kementerian Pendidikan dan Kebudayaan Republik Indonesia, 2016). Hal ini menyebabkan rendahnya kualitas lulusan yang pada akhirnya berdampak pada jumlah pengangguran yang lebih tinggi dibanding lulusan SMA. Hal senada juga disampaikan oleh Sutikno (2014) bahwa permasalahan yang dominan terjadi di SMK saat ini adalah belum mampunya sekolah dalam mengelola dan melaksanakan program pendidikan yang sesuai dengan kebutuhan dunia usaha dan dunia industri serta tuntutan masyarakat.

Mengacu pada kompleksitas permasalahan tersebut, maka para pelaksana pendidikan kejuruan hendaknya selalu melakukan perbaikan dan peningkatan mutu pendidikan beserta seluruh aspek di dalamnya secara sistematis, terencana, dan berkelanjutan. Konsep mutu pada dasarnya memiliki makna yang luas dan bervariasi, bahkan Sallis (2008) mengemukakan mutu sebagai slippery concept atau konsep yang licin. Maka tidak heran, jika setiap ahli memberikan definisi yang berbeda satu sama lain. Mutu atau kualitas merupakan sarana untuk menciptakan dan mempertahankan keunggulan kompetitif dalam suatu organisasi (Frangou, 1997). Komponen mutu meliputi kualitas stakeholders, kualitas professional, serta kualitas proses, desain, dan operasi proses pelayanan (Patel, 1994). Mutu pendidikan tidak semata-mata ditentukan dan dinilai oleh pemimpin pendidikan, melainkan oleh stakeholder dan khalayak umum. Mutu dalam konteks pendidikan menurut Pendidikan Menengah Umum (1999) mengacu pada input (siswa, guru, kepala sekolah, staf tata usaha, sarana prasarana, serta kurikulum), process (layanan pembelajaran, layanan konseling, 
kepemimpinan kepala sekolah, budaya sekolah, serta hubungan sekolah dengan masyarakat), serta output (prestasi sekolah dan siswa yang dihasilkan melalui proses pembelajaran dan manajemen sekolah)

Sementara itu, menurut Leba dan Padmomartono (2014) mutu bidang pendidikan dapat dinilai melalui lima aspek, yakni output, pelayanan, sumber daya manusia (tenaga pendidik dan kependidikan), aspek proses, dan aspek lingkungan Secara tidak langsung, mutu dalam pendidikan dapat diketahui melalui tiga pertanyaan, yaitu: bagaimana sumber daya di dalamnya, bagaimana proses pembelajaran yang dilaksanakan, serta bagaimana lulusan yang dihasilkan. Sekolah dikatakan bermutu apabila dapat memenuhi bahkan melampaui keinginan dan harapan stakeholders serta menetapkan spesifikasi atau perincian yang tinggi (Sallis, 2010). Sekolah bermutu memiliki pola kerja yang terpadu, baik pada tataran kebijakan sistem nasional, institusi, manajerial, maupun tataran teknis, sehingga terdapat sinkronisasi dan sinergi antar setiap tataran (Rahmah, 2018). Mutu pendidikan dapat diketahui berdasarkan tingkat kesesuaian antara penyelenggaraannya dengan standar nasional pendidikan pada satuan Pendidikan Dasar dan Pendidikan Menengah dan/atau program keahlian (Kemendikbud RI, 2016). Oleh karenanya, sekolah dikatakan bermutu apabila dalam praktiknya mampu memberikan layanan pendidikan yang sesuai atau bahkan melampaui dari harapan dan keinginan stakeholder.

Kaitannya dengan upaya perbaikan dan peningkatan mutu guna menghasilkan lulusan yang berkompeten, tentu diperlukan manajemen mutu yang baik. Salah satu pendekatan yang dapat dijadikan acuan dalam manajemen mutu ialah Total Quality Management (TQM) atau manajemen mutu terpadu. TQM merupakan suatu pedekatan dalam menjaga keberlangsungan organisasi dengan memaksimalkan daya saing organisasi melalui perbaikan terus menerus atas produk, jasa, sumberdaya, proses, dan lingkungannya (Veithzal \& Murni, 2009). TQM sebagai filsafat dan metodologi memiliki andil yang cukup besar dalam membantu lembaga mengelola perubahan dan menetapkan upaya untuk dapat mengatasi tekanan eksternal (Sallis, 2008). Karakteristik yang ditekankan dalam TQM ialah adanya upaya perbaikan secara terus menerus atau continuous improvement. Untuk itu diperlukan adanya kegiatan yang mengarah pada kontrol dan monitoring mutu atau pengendalian mutu (quality control). Orientasi terhadap mutu membutuhkan sistem penjaminan mutu agar mutu dapat ditingkatkan secara berkelanjutan (Sulaiman \& Wibowo, 2016). Sebab dalam praktik pendidikan, pengendalian mutu tidak terlepas dari berbagai keterbatasan yang salah satunya ialah keterbatasan sumberdaya. Oleh karena itu diperlukan suatu upaya pengendalian mutu dalam bentuk jaminan mutu (quality assurance). Tujuannya tidak lain adalah untuk memberikan layanan pendidikan yang sesuai bahkan melebihi delapan standar nasional pendidikan, serta harapan stakeholders.

Penjaminan mutu merupakan keseluruhan proses dalam penetapan dan pemenuhan standar mutu pengelola yang dilakukan secara konsisten dan berkelanjutan, untuk dapat mencapai visi dan misi sebagai bentuk tanggung jawab dan pemenuhan janji kepada stakeholders (Ridwan, 2015). Penjaminan mutu merupakan sesuatu yang mutlak dipenuhi sebagai bentuk konsekuensi atas tuntutan stakeholder terhadap penyelenggaraan pendidikan yang berkualitas sehingga menghasilkan lulusan yang cakap dan terampil. Penjaminan dan peningkatan mutu pendidikan menjadi tanggungjawab para pemangku pendidikan bersama dengan pemerintah. Penjaminan mutu pendidikan di Indonesia telah diatur dalam Peraturan Pemerintah Republik Indonesia Nomor 19 Tahun 2005 tentang Standar Nasional Pendidikan, dimana secara eksplisit disebutkan satuan pendidikan baik jalur formal maupun nonformal wajib untuk melakukan penjaminan terhadap mutu pendidikan yang dilakukan secara bertahap, sistimatis dan terencana dalam suatu program penjaminan mutu yang memiliki target dan kerangka waktu yang jelas.

Lebih lanjut disebutkan dalam Peraturan Kementerian Pendidikan Nasional (Permendiknas) Republik Indonesia Nomor 63 Tahun 2009 Pasal 2 tentang Sistem Penjaminan Mutu Pendidikan, disebutkan bahwa tujuan akhir dari penjaminan mutu pendidikan adalah meningkatkan kecerdasan kehidupan manusia dan bangsa sebagaimana tertuang dalam Pembukaan Undang-Undang Dasar Negara Republik Indonesia Tahun 1945. Sejalan dengan kebijakan tersebut, kemudian dikembangkan sistem penjaminan mutu pendidikan yang terdiri atas dua komponen, yaitu: Sistem Penjaminan Mutu Eksternal (SPME) dan Sistem Penjaminan Mutu Internal (SPMI). SPME merupakan sistem penjaminan mutu yang dilaksanakan oleh pemerintah dan pemangku pendidikan, sedangkan SPMI merupakan sistem penjaminan mutu yang dilaksanakan oleh satuan pendidikan (Wahyuni \& 
Murtadlo, 2019). SPMI dilakukan secara mandiri oleh setiap sekolah dengan mengikuti siklus sebagaimana telah disebutkan dalam Sistem Penjaminan Mutu Pendidikan (SPMP) dan dijalankan oleh seluruh anggota sekolah. SPMI berperan sebagai sistem peringatan dini yang artinya dengan adanya SPMI yang diimplementasikan dengan cermat dan tepat dapat digunakan sebagai perbaikan dalam kaitannya dengan proses penyelenggaran pendidikan, sehingga tidak semakin memburuk (Sarmono, Supriyanto, \& Timan, 2020).

Implementasi SPMI mencakup seluruh aspek penyelenggaraan pendidikan serta melibatkan dan memanfaatkan berbagai sumberdaya yang ada untuk mencapai delapan standar nasional pendidikan. Implementasi SPMI terdiri dari lima langkah kegiatan, yaitu: 1.) Pemetaan mutu pendidikan yang dilaksanakan oleh satuan pendidikan berdasarkan standar nasional pendidikan; 2.) Pembuatan rencana peningkatan mutu yang dituangkan dalam Rencana Kerja Sekolah (RKS); 3.) Melaksanakan pemenuhan mutu baik dalam pengelolaan satuan pendidikan maupun proses pembelajaran; 4.) Monitoring dan evaluasi proses pelaksanaan pemenuhan mutu yang telah dilakukan; dan 5.) Menetapkan standar baru dan penyusunan strategi peningkatan mutu berdasarkan hasil monitoring dan evaluasi (Kemendikbud, 2016). Implementasi SPMI yang baik menghasilkan beberapa dampak positif diantaranya adalah peningkatan prestasi peserta didik, peningkatan prestasi sekolah, serta utamanya ialah daya saing lulusan yang tinggi (Darmaji, Supriyanto, \& Timan, 2019). Kebijakan sistem penjaminan mutu ini kemudian disusul dengan munculnya sekolah model dan sekolah imbas yang mulai diberlakukan oleh Lembaga Penjaminan Mutu Pendidikan (LMPM) pada tahun 2016. Sekolah model sendiri merupakan sekolah yang telah memenuhi mutu pendidikan berdasarkan pada delapan standar nasional pendidikan.

Sekolah model berkewajiban untuk mengimbaskan bagaimana praktik sistem penjaminan mutu pendidikan yang baik dan sesuai kepada lima sekolah disekitarnya. Hasil yang diharapkan adalah meningkatnya kemampuan sekolah dalam menjamin, mempertahankan, dan meningkatkan mutu pendidikannya, sehingga tercipta budaya mutu di sekolah yang pada akhirnya dapat meningkatkan mutu lulusan dan mencapai tujuan nasional pendidikan (Sukaryanti \& Supriyoko, 2020). SMK Negeri 35 Tulungagung sebagai salah satu SMK unggul dan efektif yang memiliki beberapa tujuan pendidikan, salah satunya ialah mewujudkan layanan pendidikan yang melampaui standar nasional pendidikan. SMK Negeri 35 Tulungagung merupakan sekolah model yang sejak tahun 2014 telah ditunjuk sebagai sekolah rujukan oleh Direktorat Pembinaan Sekolah Menengah Kejuruan (PSMK) untuk dapat melaksanakan penjaminan mutu internal yang implementasinya adalah mampu meningkatkan capaian standar nasional pendidikan. SMK Negeri 35 Tulungagung juga telah tersertifikasi ISO 9001:2015 yang membuktikan bahwa proses dan layanan pendidikan yang diberikan telah terstandarisasi. Hal ini berarti SMK Negeri 35 Tulungagung telah mampu merencanakan, memelihara, dan meningkatkan mutu pendidikannya secara berkelanjutan sesuai pada delapan standar nasional pendidikan.

Penelitian terkait penjaminan mutu pendidikan pernah dilakukan oleh Fathoni (2008), dalam penelitiannya yang berjudul Peningkatan kualitas pendidikan melalui sistem penjaminan mutu. Tujuan penelitian Fathoni (2008) tersebut untuk memperoleh gambaran komprehensif tentang pemahaman pengelola sekolah tentang sistem penjaminan mutu, mengungkapkan proses penetapan standar mutu yang meliputi standar mutu yang diterapkan di masing-masing sekolah, cara pengelola sekolah menetapkan standar mutu, dan faktor-faktor yang menjadi dasar penetapan standar mutu, serta memberikan gambaran strategi sekolah dalam mencapai standar mutu yang telah ditetapkan. Temuan penelitian tersebut berupa perspektif pengelola sekolah sebagai wujud dari kebaikan sesuatu yang tercermin dalam ketercapaian standar atau indikator mutu melalui proses yang baik, sehingga memenuhi harapan pelanggan dan memberikan nilai manfaat bagi pelanggannya, standar mutu minimal yang harus dimiliki lembaga pendidikan Islam, serta langkah-langkah pencapaian mutu pendidikan yang secara keseluruhan mencakup tiga tahap yaiu planning, implementating, dan controlling.

Berdasarkan latar belakang dan alur pikir sebagaimana yang telah dipaparkan, maka dalam artikel ini penulis menguraikan implementasi sistem penjamiman mutu disalah satu pendidikan menengah kejuruan favorit di Kabupaten Tulungagung melalui judul Implementasi Sistem Penjaminan Mutu Internal (SPMI) di Sekolah Menengah Kejuruan (SMK). 


\section{METODE}

Penelitian yang dilaksanakan menggunakan pendekatan kualitatif, yaitu mengungkapkan fenomena melalui pengumpulan data pada kondisi objek yang alami dimana peneliti berperan sebagai instrumen kunci yang kehadirannya mutlak diperlukan. Data dalam penelitian ini adalah data terkait implementasi penjaminan mutu di SMK Negeri 35 Tulungagung. Sementara sumber datanya ialah wakil kepala sekolah bidang kurikulum dan perwakilan anggota Tim Penjaminan Mutu Pendidikan Sekolah (TPMPS). Data diperoleh menggunakan teknik observasi, wawancara, dan studi dokumentasi. Data yang diperoleh dianalisis melalui tiga tahapan kegiatan, yaitu reduksi data, penyajian data, dan penarikan kesimpulan. Untuk menguji keabsahan sumber data temuan pada penelitian ini, penulis menggunakan teknik triangulasi data. Triangulasi data merupakan penguatan bukti dari berbagai sumber data untuk menghasilkan hasil yang akurat dan terpercaya.

\section{HASIL DAN PEMBAHASAN}

Hasil

SMK Negeri 35 Tulungagung merupakan salah satu sekolah kejuruan favorit di Kabupaten Tulungagung yang diminati banyak lulusan, terbukti dengan banyaknya pendaftar setiap tahunnya. Sekolah tersebut telah mengimplementasikan penjaminan mutu pendidikan sesuai delapan standar nasional pendidikan. Sistem Penjaminan Mutu Internal (SPMI) di SMKN 35 Tulungagung bertujuan untuk memberikan pelayanan sesuai dengan delapan standar nasional pendidikan, sehingga dapat melampaui harapan pengguna layanan pendidikan. Lulusannya memiliki keterampilan sesuai jurusan yang ditempuh untuk digunakan sebagai bekal dalam memasuki dunia kerja. Hal ini dapat dilihat dari banyaknya lulusan yang diterima bekerja di berbagai bidang industri. Sementara sisanya mampu melanjutkan ke pendidikan tinggi negeri maupun swasta.

Berdasarkan hasil wawancara, prosedur pelaksanaan sistem penjaminan mutu internal di SMK Negeri 35 Tulungagung secara garis besar telah sesuai dengan pedoman pelaksanaan sistem penjaminan mutu internal di tingkat SMA/MA/SMK, kalaupun ada perbedaan itu hanya sebagai kecil yang dikarenakan kondisi dan karakteristik sekolah atau daerah yang berbeda satu dengan yang lain. Implementasi sistem penjaminan mutu internal di SMK Negeri 35 Tulungagung dimulai dari pemetaan mutu yang dilaksanakan melalui Evaluasi Diri Sekolah (EDS). Melalui evaluasi diri sekolah inilah diperoleh sejumlah data dan informasi. Data dan informasi tersebut selanjutnya diolah melalui sistem informasi milik pemerintah sehingga mampu secara akurat menunjukkan nilai capaian mutu dari setiap aspek standar nasional pendidikan. Hasil pemetaan mutu kemudian dianalisis lebih lanjut untuk mengetahui capaian mutu yang dirasa kurang sehingga dapat diperbaiki dengan beracuan pada prosedur sistem penjaminan mutu internal. Pemetaan mutu tahun ajaran 2017/2018 memperoleh nilai keseluruhan 3,3. Untuk lebih jelasnya dapat dilihat pada Gambar 1.

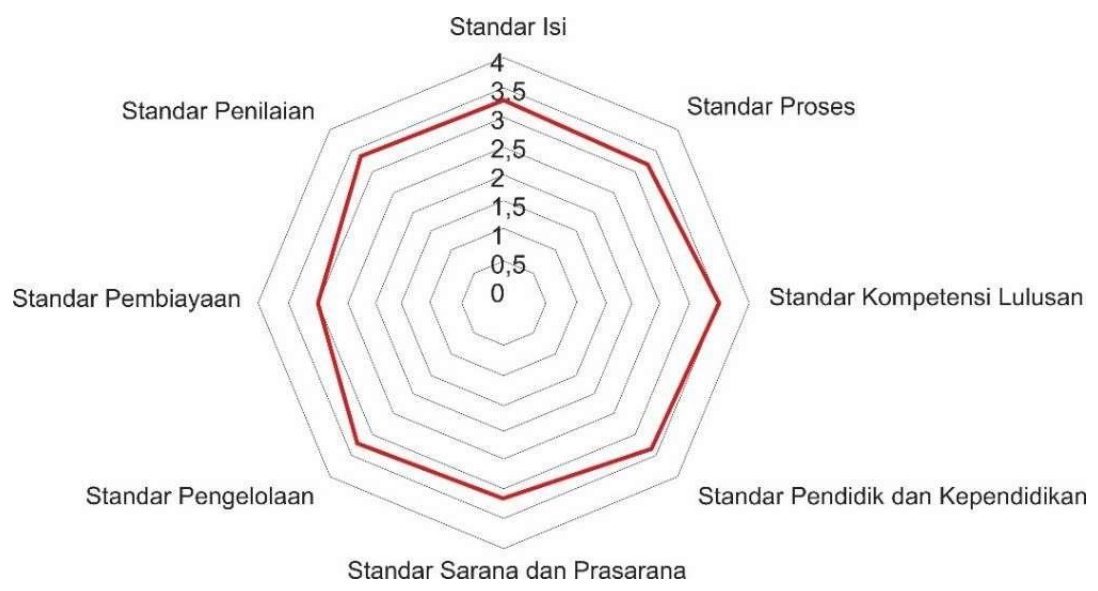

Gambar 1. Capaian Mutu SMK Negeri 35 Tulungagung Tahun Ajaran 2017/2018 
Hasil pemetaan mutu ditindaklanjuti dengan penyusunan rencana pemenuhan mutu, pelaksanaan pemenuhan mutu, monitoring dan evaluasi, serta penetapan standar baru pemenuhan mutu berdasarkan hasil monitoring dan evaluasi. Hasil evaluasi pemenuhan mutu tahun ajaran 2018/2019 mengalami peningkatan sebesar 0,2 menjadi 3,5. Hasil ini dapat dilihat pada Gambar 2 .

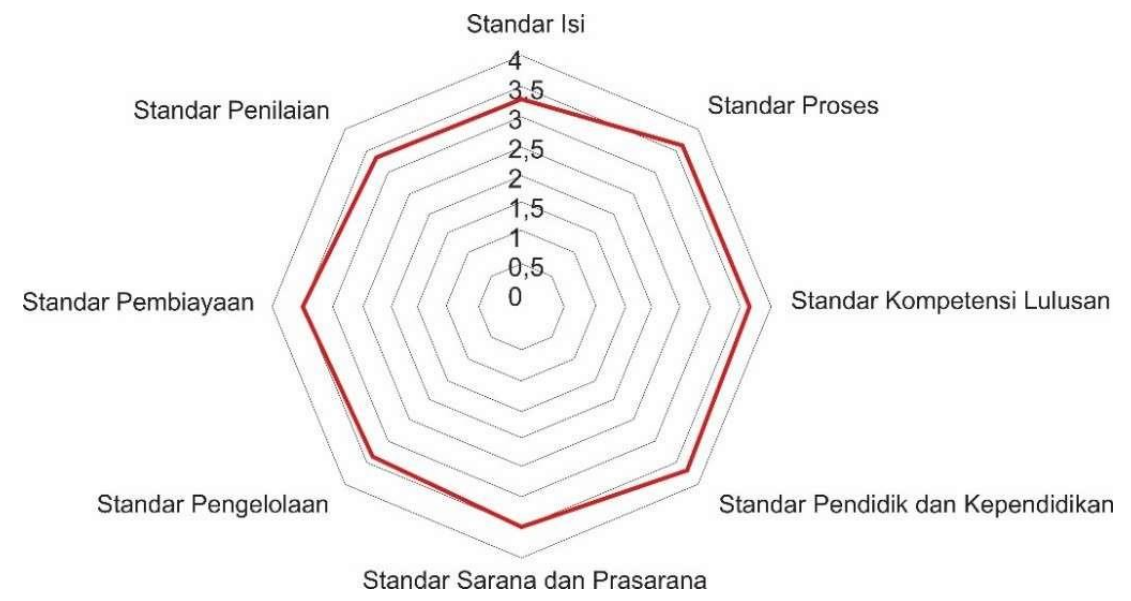

Gambar 2. Capaian Mutu SMK Negeri 35 Tulungagung Tahun Ajaran 2018/2019

Pembahasan

Sistem Penjaminan Mutu Internal di SMK Negeri 35 Tulungagung dilaksanakan oleh Tim Penjaminan Mutu Pendidikan Sekolah (TPMPS) yang terdiri dari kepala sekolah sebagai penang gungjawab serta guru, staf, dan perwakilan komite sekolah. Ditegaskan pula oleh narasumber, bahwa sebagai salah satu sekolah model, pihak SMK Negeri 35 Tulungagung mengupayakan penjaminan mutu semaksimal mungkin serta mengimbaskan pada sekolah-sekolah disekitarnya sesuai amanat pemerintah. Implementasi sistem penjaminan mutu internal dilakukan secara komprehensif dengan melibatkan seluruh unsur sekolah. Paradigma penjaminan mutu harus dilakukan secara bersamasama dengan melibatkan seluruh komponen sekolah. Kepala sekolah, guru, dan karyawan harus menjadi tim kerja yang saling utuh, saling membantu, memberi dukungan, dorongan, dan melengkapi satu sama lain (Saifulloh, Muhibbin, \& Hermanto, 2012).

Penjaminan mutu di SMK Negeri 35 Tulungagung bermula dari Evaluasi Diri Sekolah (EDS). Evaluasi diri sekolah di SMK Negeri 35 Tulungagung dilaksanakan setiap akhir tahun pembelajaran dengan melibatkan seluruh komponen sekolah. Evaluasi diri sekolah di SMK Negeri 35 meliputi beberapa tahapan kegiatan, yaitu penyusunan instrumen, pengumpulan data, pengolahan data, analisis data, dan pembuatan peta mutu yang mengacu pada standar nasional pendidikan. Kepala sekolah sebagai pendukung pengawas untuk melaksanakan evaluasi diri sekolah bersama Tim Penjaminan Mutu Pendidikan Sekolah (TPMPS). Hal yang perlu diperhatikan dalam memperoleh data evaluasi diri sekolah ialah kejujuran pengisi dan akurasi data. Sebagaimana dikemukakan Gustini dan Mauly (2019) bahwa sekecil apapun data yang ada merupakan informasi yang sangat penting, sebagai dasar untuk proses peningkatan mutu satuan pendidikan.

Pemetaan mutu dilakukan pada setiap satuan standar nasional pendidikan termasuk komponen serta masing-masing indikator di dalamnya, dan didukung dengan bukti fisik. Contohnya silabus, RPP, instrumen penilaian, instrumen supervisi, dan lain sebagainya. Lebih baik jika hasil pemetaan mutu yang diperoleh dari evaluasi diri sekolah disajikan secara singkat namun informatif (Kemendikbud RI, 2016). Selanjutnya dilakukan pengecekan kebenaran data, olah data, dan analisis data oleh Tim Penjaminan Mutu Pendidikan Sekolah untuk dapat menghasilkan data yang mutakhir dan akurat yang mampu mempresentasikan capaian mutu SMK Negeri 35 Tulungagung terhadap standar nasional pendidikan. Di dalamnya, diuraikan pula masalah yang dihadapi oleh sekolah dalam kurun waktu satu tahun pada masing-masing satuan standar nasional pendidikan, serta rekomendasi yang diberikan oleh Tim Penjaminan Mutu Pendidikan Sekolah untuk perbaikan ke depannya. 
Berdasarkan hasil pemetaan mutu akan disusun skala prioritas kebutuhan yang kemudian menjadi dasar penyusunan rencana pemenuhan atau peningkatan mutu. Dalam menyusun rencana pemenuhan mutu Tim Penjaminan Mutu Pendidikan Sekolah akan mempertimbangkan berbagai aspek antara lain visi misi sekolah, kebijakan internal sekolah, serta kebijakan pusat dan daerah. Hal ini dimaksudkan agar rencana pemenuhan mutu dapat mencapai standar nasional pendidikan dengan tetap mengacu pada efektivitas tujuan sekolah. Rencana pemenuhan mutu yang telah disusun selanjutnya dituangkan dalam bentuk dokumen perencanaan mutu atau Rencana Kerja Sekolah (RKS) baik jangka menengah maupun jangka panjang. RKS disusun secara sistematis mencakup berbagai komponen, selanjutnya diuraikan secara spesifik yaitu terkait bentuk program pemenuhan mutu, tujuan, strategi pelaksanaan, indikator keberhasilan, serta rincian biaya yang dibutuhkan.

RKS yang telah disusun mula-mula diajukan pada kepala sekolah untuk diteliti dan ditindaklanjuti. Apabila dirasa telah sesuai maka RKS akan disetujui dan disahkan oleh kepala sekolah. Setelah disahkan, barulah RKS dapat disosialisasikan pada seluruh anggota sekolah. Selesai dilakukan kegiatan sosialisasi, rencana pemenuhan mutu selanjutnya direalisasikan dan dilaksanakan secara menyeluruh dengan melibatkan seluruh komponen sekolah baik kepala sekolah, guru, karyawan, siswa, dan orangtua siswa. Saat ini, hampir seluruh komponen di SMK Negeri 35 Tulungagung telah memiliki kesadaran dan komitmen yang tinggi untuk melaksanakannya. Prosedur yang ditempuh secara keseluruhan meliputi tiga tahap, dimulai dari persiapan, penyusunan RKS, dan dilanjutkan dengan pengesahan RKS. Hal ini sesuai dengan petunjuk yang telah ditetapkan oleh Kementerian Pendidikan dan Kebudayaan Republik Indonesia Tahun 2016.

Pelaksanaan pemenuhan mutu di SMK Negeri 35 Tulungagung, selalu dimonitor oleh Tim Penjaminan Mutu Pendidikan Sekolah agar dapat berjalan sesuai dengan tujuan yang diharapkan. Selanjutnya, dilakukan evaluasi terhadap pelaksanaan pemenuhan mutu melalui evaluasi diri sekolah. Evaluasi ini bertujuan untuk mengetahui efektifitas pelaksanaan pemenuhan mutu serta kesesuaiannya dengan rencana pemenuhan mutu, guna menjamin terjadinya peningkatan mutu secara berkelanjutan. Berdasarkan hasil evaluasi ini, selanjutnya akan dilakukan penetapan standar mutu baru sebagai upaya pemenuhan mutu kedepannya. Standar mutu yang menjadi acuan dalam penyelenggaraan pendidikan di SMK Negeri 35 Tulungagung. Proses penetapan standar mutu di SMK Negeri 35 Tulungagung melibatkan seluruh personil sekolah. Standar mutu yang menjadi acuan penyelenggaraan pendidikan yang bermutu utamanya adalah delapan standar nasional pendidikan, Permendikbud Nomor 28 tahun 2016 tentang Sistem Penjaminan Mutu Pendidikan Dasar dan Menengah, serta kebijakan pemerintah lain yang sesuai.

Penetapan standar mutu di SMK Negeri 35 Tulungagung juga didasarkan pada visi misi dan tujuan sekolah serta disesuaikan dengan kemampuan sekolah. Standar mutu di SMK Negeri 35 Tulungagung dapat berubah seiring waktu dan mengikuti tuntutan kualitas yang diharapkan stakeholders. Nanang (2012) menyebutkan bahwa orangtua, masyarakat, pemerintah, dan pihakpihak lain di dunia usaha dan industri sebagai stakeholders pendidikan yang seringkali memiliki persepsi yang berbeda tentang mutu pendidikan. Oleh karena itu, sekolah perlu menanggapi segala perubahan dengan penetapan standar mutu sebagai acuan dalam mencapai sekolah yang bermutu (Sodiq \& Haryana, 2017). Seluruh langkah penjaminan mutu yang dilaksanakan di SMK Negeri 35 Tulungagung menghasilkan catatan atau rapor Sistem Penjaminan Mutu Internal (SPMI) dengan hasil yang baik.

\section{SIMPULAN}

SMKN 35 Tulungagung merupakan salah satu SMK yang telah tersertifikasi ISO 9001:2015 yang membuktikan bahwa proses dan layanan pendidikan yang diberikan telah terstandarisasi. Sampai saat ini SMKN 35 Tulungagung selalu berupaya memperbaiki dan meningkatkan mutu pendidikan sehingga dapat memberikan kepuasan pada stakeholders. Hal ini diwujudkan melalui SPMI dan dilaksanakan oleh TPMPS yang terdiri dari kepala sekolah, guru, karyawan, dan komite. Namun demikian, impementasi SPMI tetap melibatkan peran serta seluruh komponen sekolah. SPMI di SMKN 35 Tulungagung bertujuan untuk memberikan pelayanan sesuai dengan delapan SNP, sehingga dapat melampaui harapan pengguna layanan pendidikan. 
Penjaminan mutu di SMKN 35 Tulungagung bermula dari Evaluasi Diri Sekolah (EDS). Dari EDS inilah diperoleh data yang menunjukkan nilai capaian mutu dari setiap aspek SNP. Selanjutnya dilakukan penyusunan rencana pemenuhan mutu yang mengarah pada delapan SNP. Pelaksanaan pemenuhan mutu dijalankan oleh seluruh anggota sekolah dengan selalu dimonitor oleh kepala sekolah bersama dengan TPMPS dan dilakukan evaluasi setiap satu tahun pembelajaran untuk melihat dan menilai efektifitas pelaksanaan dengan perencanaan terhadap tujuan yang diinginkan. Hasilnya dianalisis guna menentukan dan menetapkan standar baru pemenuhan mutu yang lebih baik kedepannya. Seluruh tahapan tersebut didokumentasikan dalam bentuk rapor mutu sekolah. Sejauh ini, implementasi SPMI di SMKN 35 Tulungagung mendapatkan rapor mutu yang baik.

\section{DAFTAR PUSTAKA}

Badan Pusat Statistik. (2019). Tingkat pengangguran terbuka sebesar 5,01 persen. Retrieved from https://www.bps.go.id/pressrelease/2019/05/06/1564/februari-2019-tingkat-pengangguranterbuka--tpt--sebesar-5-01-persen.html

Darmaji, D., Supriyanto, A., \& Timan, A. (2019). Sistem Penjaminan Mutu Internalsekolah Untuk Meningkatkan Mutu Lulusan. JMSP (Jurnal Manajemen dan Supervisi Pendidikan), 3(3), 130-136. doi: http://dx.doi.org/10.17977/um025v3i32019p130

Fathoni, M. (2008). Peningkatan kualitas pendidikan melalui sistem penjaminan mutu (Studi multi situs di SD Al Falah Tropodo 2 Sidoarjo, SDIT Bina Insani Kediri, dan SDIT Al Hikmah Blitar) (Unpublished doctoral dissertation). Universitas Negeri Malang, Indonesia.

Frangou, A. J. (1997). Towards a case-based intelligent system for competitive advantage (Unpublished doctoral dissertation). University of Portsmouth, United Kingdom.

Gustini, N., \& Mauly, Y. (2019). Implementasi sistem penjaminan mutu internal dalam meningkatkan mutu pendidikan dasar. Jurnal Isema: Islamic Education Management, 4(2). 229-244. Retrieved from http://journal.uinsgd.ac.id/index.php/isema/article/view/5695

Kementerian Pendidikan dan Kebudayaan Republik Indonesia. (2016). Petunjuk pelaksanaan penjaminan mutu pendidikan oleh satuan pendidikan. Jakarta: Kementerian Pendidikan dan Kebudayaan Republik Indonesia.

Kementerian Pendidikan Nasional Republik Indonesia. (2009). Peraturan Kementerian Pendidikan Nasional (Permendiknas) Republik Indonesia Nomor 63 Tahun 2009 Pasal 2 tentang Sistem Penjaminan Mutu Pendidikan.

Leba, U. T. I., \& Padmomartono, S. (2014). Profesi kependidikan. Yogyakarta: Ombak (Anggota IKAPI).

Nanang, F. (2012). Sistem penjaminan mutu pendidikan. Bandung: PT Remaja Rosdakarya.

Qomar, M. (2010). Manajemen Pendidikan Islam. Jakarta: Erlangga

Patel, A. (1994). Quality assurance (BS 5750) in social services departments. International Journal of Public Sector Management, 7(2), 4-15. doi: https://doi.org/10.1108/09513559410055198

Putri, Z. D. (2020). Implementasi standar pengelolaan pendidikan SMK Negeri 1 Bengkalis. Jurnal Pendidikan MINDA, 1(2), 61-73. Retrieved from http://www.ejurnal.universitaskarimun.ac.id/index.php/mindafkip/article/view/124/96

Pendidikan Menengah Umum. (1999). Peningkatan mutu pendidikan berbasis sekolah: Suatu. konsepsi otonomi sekolah. Jakarta: Departemen Pendidikan dan Kebudayaan Republik Indonesia.

Presiden Republik Indonesia. (2005). Peraturan Pemerintah Republik Indonesia Nomor 19 Tahun 2005 tentang Standar Nasional Pendidikan. 
Presiden Republik Indonesia. (2010). Peraturan Pemerintah (PP) tentang Perubahan Atas Peraturan Pemerintah Nomor 17 Tahun 2010 Tentang Pengelolaan Dan Penyelenggaraan Pendidikan.

pwmu.co. (2017, Desember 15). Hasil lengkap akreditasi sekolah SMA/MA dan SMK se-Jawa Timur 2017. Retrieved from https://pwmu.co/45651/12/15/hasil-lengkap-akreditasisekolah-sma-ma-dan-smk-se-jawa-timur-2017/

Sodiq, R., \& Haryana, K. (2017). Evaluasi penjaminan mutu pendidikan Di SMK Negeri 1 Magelang. E-Jurnal Pendidikan Teknik Otomotif-S1, 18(2), 111-121. Retrieved from http://journal.student.uny.ac.id/ojs/ojs/index.php/otomotif-s1/article/view/10131/9695

Rahmah, U. (2018). The Implementasi Total Quality Management (TQM) di SD Al-Hikmah Surabaya. MANAGERIA: Jurnal Manajemen Pendidikan Islam, 3(1), 111-131. doi: https://doi.org/10.14421/manageria.2018.31-06

Ridwan, A. (2015). Penjaminan mutu sekolah. PT Bumi Aksara.

Saifulloh, M., Muhibbin, Z., \& Hermanto, H. (2012). Strategi peningkatan mutu pendidikan di sekolah. Jurnal Sosial Humaniora, 206-218. Retrieved from http://www.iptek.its.ac.id/index.php/jsh/article/download/619/341

Sallis, E. (2008). TQM in higher education. Kogan Page.

Sallis, E. (2010). Manajemen mutu terpadu pendidikan: Peran strategis pendidikan di era globalisasi modern. (Ahmad Ali Riyadi \& Fahrurrozi Trans.). Yogyakarta: IRCiSoD.

Sarmono, A., Supriyanto, A., \& Timan, A. (2020). Penerapan manajemen mutu terpadu pada sistem penjaminan mutu pendidikan internal. JAMP: Jurnal Administrasi Dan Manajemen Pendidikan, 3(1), 38-51. Retrieved from http://journal2.um.ac.id/index.php/jamp/article/view/7739/5230

Sukaryanti, B. (2020). Manajemen sekolah model sistem penjaminan mutu internal di SMP Muhammadiyah 2 Yogyakarta. Media Manajemen Pendidikan, 2(3), 362-371. doi: https://doi.org/10.30738/mmp.v2i3.6739

Sulaiman, A., \& Wibowo, U. B. (2016). Implementasi sistem penjaminan mutu internal sebagai upaya meningkatkan mutu pendidikan di Universitas Gadjah Mada. Jurnal Akuntabilitas Manajemen Pendidikan, 4(1), 17-32. doi: https://doi.org/10.21831/amp.v4i1.8197

Sutikno, T. A. (2014). Manajemen strategik pendidikan kejuruan dalam menghadapi persaingan mutu. Teknologi dan Kejuruan: Jurnal teknologi, Kejuruan, dan Pengajarannya, 36(1). doi: http://dx.doi.org/10.17977/tk.v36i1.4073

Wahyuni, R. R. W., \& Murtadlo, M. (2019). Implementasi Sistem Penjaminan Mutu Internal (SPMI) pada Sekolah Menengah Kejuruan Negeri 1 Surabaya. Inspirasi Manajemen Pendidikan, 7(1), Retrieved from https://jurnalmahasiswa.unesa.ac.id/index.php/inspirasi-manajemenpendidikan/article/view/29153/26696

Veithzal, R., \& Murni, S. (2009). Education management: Analisis teori dan praktik. Raja Grafindo Persada. 